\title{
Raman, infrared and near-infrared spectroscopic characterization of the herderite-hydroxylherderite mineral series
}

\section{Ray L. Frost ${ }^{\mathrm{a}, *}$, Ricardo Scholz ${ }^{\mathrm{b}}$, Andrés López ${ }^{\mathrm{a}}$, Yunfei Xi ${ }^{\mathrm{a}}$, Camila de Siqueira Queiroz ${ }^{\mathrm{b}}$, Fernanda M. Belotti ${ }^{\mathrm{c}}$, Mauro Cândido Filho ${ }^{\mathrm{d}}$}

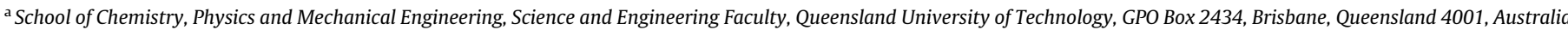
${ }^{\mathrm{b}}$ Geology Department, School of Mines, Federal University of Ouro Preto, Campus Morro do Cruzeiro, Ouro Preto, MG 35400-00, Brazil

${ }^{\mathrm{c}}$ Federal University of Itajubá, Campus Itabira, Itabira, MG, Brazil

${ }^{\mathrm{d}}$ Mining Engineering Department, School of Mines, Federal University of Ouro Preto, Campus Morro do Cruzeiro, Ouro Preto, MG 35400-00, Brazil

\section{H I G H L I G H T S}

- We have studied herderitehydroxylherderite series from Brazil. - $\mathrm{CaBePO}_{4}(\mathrm{~F}, \mathrm{OH})$ was investigated by an electron microprobe.

- The minerals occur as secondary products in granitic pegmatites.

-We studied the minerals using vibrational spectroscopy.

- Hydrogen bond distances were calculated.

\section{G R A P H I C A L A B S T R A C T}

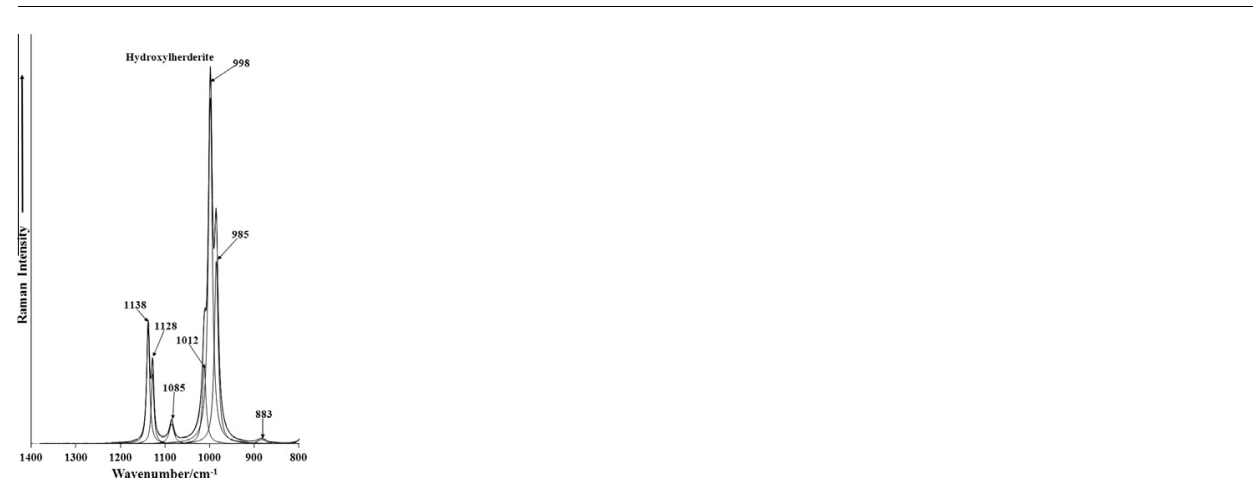

\section{A R T I C L E I N F O}

\section{Article history:}

Received 10 June 2013

Received in revised form 27 August 2013

Accepted 2 September 2013

Available online 13 September 2013

\section{Keywords}

Raman spectroscopy

Herderite

Hydroxylherderite

Phosphate

Beryllium

Pegmatite

\begin{abstract}
A B S T R A C T
Natural single-crystal specimens of the herderite-hydroxylherderite series from Brazil, with general formula $\mathrm{CaBePO}_{4}(\mathrm{~F}, \mathrm{OH})$, were investigated by electron microprobe, Raman, infrared and near-infrared spectroscopies. The minerals occur as secondary products in granitic pegmatites. Herderite and hydroxylherderite minerals show extensive solid solution formation. The Raman spectra of hydroxylherderite are characterized by bands at around 985 and $998 \mathrm{~cm}^{-1}$, assigned to $v_{1}$ symmetric stretching mode of the $\mathrm{HOPO}_{3}^{3-}$ and $\mathrm{PO}_{4}^{3-}$ units. Raman bands at around 1085,1128 and $1138 \mathrm{~cm}^{-1}$ are attributed to both the HOP and PO antisymmetric stretching vibrations. The set of Raman bands observed at 563, 568, 577, 598,616 and $633 \mathrm{~cm}^{-1}$ are assigned to the $v_{4}$ out of plane bending modes of the $\mathrm{PO}_{4}$ and $\mathrm{H}_{2} \mathrm{PO}_{4}$ units. The $\mathrm{OH}$ Raman stretching vibrations of hydroxylherderite were observed ranging from $3626 \mathrm{~cm}^{-1}$ to $3609 \mathrm{~cm}^{-1}$. The infrared stretching vibrations of hydroxylherderites were observed between $3606 \mathrm{~cm}^{-1}$ and $3599 \mathrm{~cm}^{-1}$. By using a Libowitzky type function, hydrogen bond distances based upon the $\mathrm{OH}$ stretching bands were calculated. Characteristic NIR bands at around 6961 and $7054 \mathrm{~cm}^{-1}$ were assigned to the first overtone of the fundamental, whilst NIR bands at 10,194 and $10,329 \mathrm{~cm}^{-1}$ are assigned to the second overtone of the fundamental $\mathrm{OH}$ stretching vibration. Insight into the structure of the herderite-hydroxylherderite series is assessed by vibrational spectroscopy.
\end{abstract}

(c) 2013 Elsevier B.V. All rights reserved.

\footnotetext{
* Corresponding author. Tel.: +61 73138 2407; fax: +61 731381804 .

E-mail address: r.frost@qut.edu.au (R.L. Frost).
}

\section{Introduction}

Beryllium is a typical chemical element found in granitic pegmatites, especially in the structure of silicates such as beryl $\left[\mathrm{Be}_{3} \mathrm{Al}_{2}\left(\mathrm{Si}_{6} \mathrm{O}_{18}\right)\right]$, phenakite $\left(\mathrm{Be}_{2} \mathrm{SiO}_{4}\right)$, euclase $\left[\left(\mathrm{BeAl}\left(\mathrm{SiO}_{4}\right)(\mathrm{OH})\right]\right.$ 
and bertrandite $\left[\mathrm{Be}_{4}\left(\mathrm{Si}_{2} \mathrm{O}_{7}\right)(\mathrm{OH})_{2}\right]$, and the oxide chrysoberyl $\left(\mathrm{BeAl}_{2} \mathrm{O}_{4}\right)$. Beryllium metal is an important element in industry with different applications in metallurgy especially in the production of copper, aluminum and magnesium alloys; however, the use is limited due to the high price and toxicity. Beryllium has also importance for the defence and aerospace industry, due to its stiffness, light weight and dimensional stability over a wide temperature range. Despite the importance for industry, the major field of use of beryllium minerals is in the gemstones and jewelry market, mainly, emerald and aquamarine [1].

Be phosphates are relatively rare in nature and are related to a range of temperature and pressure during the pegmatite evolution [2], occurring from the magmatic process [3,4] to the hydrothermal and supergene [5,6]. Černý [7] and Černá et al. [8] describes beryllium phosphates as secondary product of late alteration of beryl. The most common Be phosphates are hydroxylherderite, moraesite, beryllonite and the members of the roscherite group [7-10]. Herderite and hydroxylherderite are two rare gemstones and also shows importance in the mineral collectors market [11-13]. Herderite was first described from samples associated with the Sn-bearing pegmatites at Ehrenfriedersdorf in the Erzgebirge of Germany [14], and hydroxylherderite was first described from the mineral District of Paris, Maine, USA by Penfield [15] as hydro-herderite. Later, Palache et al. [16] were responsible to establish the herderite-hydroxylherderite series. Byrappa and Pushcharovsky [17] have observed the structural similarity between hydroxylherderite and datolite. Chrystallographic studies were carried out by Lager and Gibbs [18] in hydroxylherderite from Golconda pegmatite, in Brazil and Harlow and Hawthorn [19] have solved the crystal structure of herderite from Mogok, Myanmar.

According to Lager and Gibbs [18], hydroxylherderite crystallizes in the monoclinic system, $P 2_{1} / a$ space group, with $a=9.789(2) \AA, \quad b=7.661(1) \AA, \quad c=4.804(1) \AA$ and $\beta=90.02(1)^{\circ}$. Hydroxylherderite consists of sheets of corner-sharing $\mathrm{PO}_{4}$ and $\mathrm{BeO}_{3} \mathrm{OH}$ tetrahedra linked along the $c$ axis by sheets of edge-sharing Ca-containing polyhedral. Each tetrahedral sheet contains alternating $\mathrm{PO}_{4}$ and $\mathrm{BeO}_{3} \mathrm{OH}$ polyhedral which form a network of four- and eight-membered centro-symetric rings extending parallel to (001). Herderite, as described by Harlow and Hawthorn [19] crystallizes in monoclinic crystal system, space group $P 2_{1} / a$, with $a=9.7446(4) \AA, \quad b=7.6769(3) \AA, \quad c=4.7633(2) \AA, \quad \beta=90.667(1)^{\circ}$, $V=356.31(4) \AA^{3}$, and $Z=4$. The authors cited that as effect of increasing of herderite content, generally occurs a contraction of the structure, with a decrease in $a, c$, and $V$ and the increase in $b$. The relation $\mathrm{F}-\mathrm{OH}$ in herderite and hydroxylherderite were also studied in different ways. In a systematic optical and chemical characterization, Leavens et al. [20] have described the dependence of the refractive index with the $\mathrm{F} / \mathrm{OH}$ ratios and have established the increase of refractive index to the decrease of $F$ content.

In the infrared spectroscopic characterization of the amblygonite-montebrasite mineral series, Fransolet and Tarte [21] established a correlation between $\mathrm{OH}$ wavenumbers $\left(v_{\mathrm{OH}}\right.$ in the region between $3400-3350 \mathrm{~cm}^{-1}$ and $\delta_{\mathrm{OH}}$ in the $840-800 \mathrm{~cm}^{-1}$ region) and the fluorine content. With the application of Raman spectroscopy, Rondeau et al. [22] have observed correlation between the $\mathrm{F}$ content with the position of 3 characteristic Raman peaks and the full width at medium height (FWMH) of the peak around $3370 \mathrm{~cm}^{-1}$.

Farmer [23] divided the vibrational spectra of phosphates according to the presence, or absence of water and hydroxyl units in the minerals. In aqueous systems, Raman spectra of phosphate oxyanions show a symmetric stretching mode $\left(v_{1}\right)$ at $938 \mathrm{~cm}^{-1}$, the antisymmetric stretching mode $\left(v_{3}\right)$ at $1017 \mathrm{~cm}^{-1}$, the symmetric bending mode $\left(v_{2}\right)$ at $420 \mathrm{~cm}^{-1}$ and the $v_{4}$ mode at $567 \mathrm{~cm}^{-1}$ [24-28]. The value for the $v_{1}$ symmetric stretching vibration of $\mathrm{PO}_{4}$ units as determined by infrared spectroscopy was given as $930 \mathrm{~cm}^{-1}$ (augelite), $940 \mathrm{~cm}^{-1}$ (wavellite), $970 \mathrm{~cm}^{-1}$ (rockbridgeite), $995 \mathrm{~cm}^{-1}$ (dufrenite) and $965 \mathrm{~cm}^{-1}$ (beraunite). The position of the symmetric stretching vibration is mineral dependent and a function of the cation and crystal structure. The fact that the symmetric stretching mode is observed in the infrared spectrum affirms a reduction in symmetry of the $\mathrm{PO}_{4}$ units.

The value for the $v_{2}$ symmetric bending vibration of $\mathrm{PO}_{4}$ units as determined by infrared spectroscopy was given as $438 \mathrm{~cm}^{-1}$ (augelite), $452 \mathrm{~cm}^{-1}$ (wavellite), 440 and $415 \mathrm{~cm}^{-1}$ (rockbridgeite), 455 , 435 and $415 \mathrm{~cm}^{-1}$ (dufrenite) and 470 and $450 \mathrm{~cm}^{-1}$ (beraunite). The observation of multiple bending modes provides an indication of symmetry reduction of the $\mathrm{PO}_{4}$ units. This symmetry reduction is also observed through the $v_{3}$ antisymmetric stretching vibrations. Augelite [28]shows infrared bands at 1205, 1155, 1079 and $1015 \mathrm{~cm}^{-1}$; wavellite at $1145,1102,1062$ and $1025 \mathrm{~cm}^{-1}$; rockbridgeite at 1145,1060 and $1030 \mathrm{~cm}^{-1}$; dufrenite at 1135,1070 and $1032 \mathrm{~cm}^{-1}$; and beraunite at 1150, 1100, 1076 and $1035 \mathrm{~cm}^{-1}$.

Published data concerning the spectroscopic characterization of beryllium phosphates are very rare in the literature. In the characterization of fluid inclusions in quartz from granitic pegmatites, Rickers et al. [29] describes Raman bands in herderite at 584, $595,983,1005 \mathrm{~cm}^{-1}$; however, the authors gave no assignment of the bands. In recent studies, in reference to the datas published by Rickers et al. [29], Frezzoti et al. [30] described Raman vibrations related to $\left(\mathrm{PO}_{4}\right)^{3-}$ anion in herderite at $584 \mathrm{~cm}^{-1}\left(v_{4}\right)$, $983 \mathrm{~cm}^{-1}\left(v_{1}\right)$ and $1005\left(v_{3}\right) \mathrm{cm}^{-1}$.

The objectives of this work are to understand the structure of herderite-hydroxylherderite minerals with the application of the vibrational spectroscopic methods infrared and Raman spectroscopy and to establish a relation between the $\mathrm{F} / \mathrm{OH}$ ratios and the position of the vibrations bands of $\mathrm{OH}^{-}$anion.

\section{Experimental}

\section{Occurrence, sample description and preparation}

For the development of this work, three natural single crystal specimens of the hydroxylherderite series were chosen. The samples were collected from different pegmatites and incorporated into the collection of the Geology Department of the Federal University of Ouro Preto, Minas Gerais, Brazil.

Sample SAA-073 was collected from the Morro Redondo mine, which belongs to the Araçuai pegmatite district, located near Coronel Murta, north of Minas Gerais. It corresponds to a bluish $3.0 \mathrm{~cm}$ single crystal and was found in association with muscovite and albite in a miarolitic cavity. Sample SAA-074 was collected from Jove Lauriano mine, located in the Conselheiro Pena pegmatite district, municipality of Divino das Laranjeiras, east of Minas Gerais. It corresponds to a single crystal up to $2 \mathrm{~cm}$ with yellowish color. The crystal was found in association with muscovite and albite in a miarolitic cavity. Samples SAA-075 and SAA-076 were also collected from pegmatites in the municipality of Divino das Laranjeiras. SAA-075 corresponds to an aggregate of $0.4 \mathrm{~cm}$ colorless single crystals and was found in association with muscovite, albite and fluorapatite in a miarolitic cavity. SAA-076 was collected from the Almerindo mine [31]. It corresponds to a yellowish single crystal, up to $2 \mathrm{~cm}$ in length and was found in association with muscovite, albite, fluorapatite and brazilianite in a miarolitic cavity. Sample SAA-093 was collected from a muscovite and topaz pegmatite in Medina, north from Minas Gerais. The single crystal shows bluish color, and occurs in association with muscovite.

The calcium and beryllium phosphates herderite and hydroxylherderite are the end member of a solid solution between fluorine and hydroxyl anions. The minerals occur in miarolitic 
cavities of granitic pegmatites, in different mineral associations. The samples were collected from five different Brazilian pegmatites. Four samples are related to lithium bearing pegmatites: SAA-073 (Morro Redondo - lepidolite and elbaite), SAA-074 (Jove Lauriano - montebrasite type and minor spodumene), SAA-075 (Osvaldo Perini - montebrasite type), SAA-076 (Almerindo - triphylite type) and one sample was collected from a muscovite-topaz rich pegmatite (Medina - SAA-093). Samples SAA-073, SAA-074 and SAA-075 are labeled as a, b, c in the figures.

The crystals were hand selected and phase analyzed by X-ray powder diffraction for simple identification. Fragments of each sample were prepared in different ways to be submitted to chemical analysis by Electron microprobe, Raman and infrared spectroscopy.

\section{Electron microprobe analysis (EMP)}

Chemical characterization was carried via EMP. Each sample selected for this study was analyzed with the performance of five spots per crystal. The chemical analysis was carried out with a Jeol JXA8900R spectrometer from the Physics Department of the Federal University of Minas Gerais, Belo Horizonte. For each selected element was used the following standards: Ca-Apatite, $\mathrm{P}-\mathrm{Ca}_{2} \mathrm{P}_{2} \mathrm{O}_{7}$, F-Fluorite, $\mathrm{Mn}$-Rhodonite, $\mathrm{Fe}-\mathrm{Magnetite}, \mathrm{Al}-\mathrm{Al}_{2} \mathrm{O}_{3}$ and $\mathrm{Mg}-\mathrm{MgO}$. Be and $\mathrm{H}_{2} \mathrm{O}$ were calculated by stoichiometry. The epoxy embedded hydroxylherderite samples were coated with a thin layer of evaporated carbon. The electron probe microanalysis in the WDS (wavelength dispersive spectrometer) mode was obtained at $15 \mathrm{kV}$ accelerating voltage and beam current of $10 \mathrm{nA}$. Chemical formula was calculated on the basis of five oxygen atoms $(\mathrm{O}, \mathrm{F}$, $\mathrm{OH})$.

\section{Raman microprobe spectroscopy}

Crystals of herderite/hydroxylherderite were placed on a polished metal surface on the stage of an Olympus BHSM microscope, which is equipped with $10 \times, 20 \times$, and $50 \times$ objectives. The microscope is part of a Renishaw 1000 Raman microscope system, which also includes a monochromator, a filter system and a CCD detector (1024 pixels). The Raman spectra were excited by a Spectra-Physics model $127 \mathrm{He}-\mathrm{Ne}$ laser producing highly polarized light at $633 \mathrm{~nm}$ and collected at a nominal resolution of $2 \mathrm{~cm}^{-1}$ and a precision of $\pm 1 \mathrm{~cm}^{-1}$ in the range between 200 and $4000 \mathrm{~cm}^{-1}$. Repeated acquisitions on the crystals using the highest magnification $(50 \times)$ were accumulated to improve the signal to noise ratio of the spectra. The spectra were collected over night. Raman Spectra were calibrated using the $520.5 \mathrm{~cm}^{-1}$ line of a silicon wafer. The Raman spectrum of at least 10 crystals was collected to ensure the consistency of the spectra.

\section{Infrared spectroscopy}

Infrared spectra were obtained using a Nicolet Nexus 870 FTIR spectrometer with a smart endurance single bounce diamond ATR cell. Spectra over the $4000-525 \mathrm{~cm}^{-1}$ range were obtained by the co-addition of 128 scans with a resolution of $4 \mathrm{~cm}^{-1}$ and a mirror velocity of $0.6329 \mathrm{~cm} / \mathrm{s}$. Spectra were co-added to improve the signal to noise ratio.

\section{Near-infrared spectroscopy}

NIR spectra were collected on a Nicolet Nexus FT-IR spectrometer with a Nicolet Near-IR Fibreport accessory (Madison, Wiscon$\sin$ ). The reason for using a fibre optic probe is the ease of operation and the fact that the probe can be brought to the mineral and can be used at some distance from the spectrometer. A white light source was used, with a quartz beam splitter and TEC NIR InGaAs detector. Spectra were obtained from 13,000 to $4000 \mathrm{~cm}^{-1}$ (0.77$2.50 \mu \mathrm{m}$ ) by the co-addition of 256 scans at a spectral resolution of $8 \mathrm{~cm}^{-1}$. A mirror velocity of $1.266 \mathrm{~m} \mathrm{~s}^{-1}$ was used. The spectra were transformed using the Kubelka-Munk algorithm to provide spectra for comparison with published absorption spectra.

Spectral manipulation such as baseline correction/adjustment and smoothing were performed using the Spectracalc software package GRAMS (Galactic Industries Corporation, NH, USA). Band component analysis was undertaken using the Jandel 'Peakfit' software package that enabled the type of fitting function to be selected and allows specific parameters to be fixed or varied accordingly. Band fitting was done using a Lorentzian-Gaussian cross-product function with the minimum number of component bands used for the fitting process. The Lorentzian-Gaussian ratio was maintained at values greater than 0.7 and fitting was undertaken until reproducible results were obtained with squared correlations of $r^{2}$ greater than 0.995 .

\section{Results and discussion}

\section{Chemical characterization}

The chemical composition of hydroxylherderite-herderite samples are presented in Table 1. For all analyzed samples the phosphorous content was slightly higher and $\mathrm{Ca}$ content slightly lower than expected for ideal herderite/hydroxylherderite composition (ideal herderite: $\left[\mathrm{P}_{2} \mathrm{O}_{5}\right] 43.53 \mathrm{wt} . \%$; [CaO] 34.39 wt.\%; hydroxylherderite: $\left[\mathrm{P}_{2} \mathrm{O}_{5}\right] 44.06 \mathrm{wt}$.\%; [CaO] $34.82 \mathrm{wt}$ \%). Low iron and manganese impurity contents were found in all four samples, and calcium impurities were found in samples SAA-073 and SAA074 .

Total formula calculations were performed considering $\mathrm{BeO}$ and $\mathrm{H}_{2} \mathrm{O}$ content calculated by stoichiometry for all samples. The $\mathrm{H}_{2} \mathrm{O}$ concentration in wt.\% was calculated for the ideal formula of $\mathrm{CaBePO}_{4}\left(\mathrm{~F}_{x} \mathrm{OH}_{1-x}\right)$ using the fluorine concentration measured by EMP. The results indicate clearly that samples SAA-073, SAA-074 and SAA-075 belong to hydroxylherderite with high $\mathrm{OH}$ content. Only sample SAA-076 shows lower OH content, belongs to an intermediate member in the herderite-hydroxylherderite series.

\section{Vibrational spectroscopy background}

In aqueous systems, the Raman spectra of phosphate oxyanions show a symmetric stretching mode $\left(v_{1}\right)$ at $938 \mathrm{~cm}^{-1}$, an antisymmetric stretching mode $\left(v_{3}\right)$ at $1017 \mathrm{~cm}^{-1}$, a symmetric bending mode $\left(v_{2}\right)$ at $420 \mathrm{~cm}^{-1}$ and a $v_{4}$ bending mode at $567 \mathrm{~cm}^{-1}$ $[25,27,32]$. S.D. Ross in Farmer listed some well-known minerals containing phosphate which were either hydrated or hydroxylated or both [23]. The vibrational spectrum of the dihydrogen phosphate anion has been reported by Farmer [23]. The $\mathrm{PO}_{2}$ symmetric stretching mode occurs at $1072 \mathrm{~cm}^{-1}$ and the $\mathrm{POH}$ symmetric stretching mode at $\sim 878 \mathrm{~cm}^{-1}$. The $\mathrm{POH}$ antisymmetric stretching mode was found at $947 \mathrm{~cm}^{-1}$ and the $\mathrm{P}(\mathrm{OH})_{2}$ bending mode at $380 \mathrm{~cm}^{-1}$. The band at $1150 \mathrm{~cm}^{-1}$ was assigned to the $\mathrm{PO}_{2}$ antisymmetric stretching mode. The position of these bands will shift according to the crystal structure of the mineral.

The vibrational spectra of phosphate minerals have been published by Farmer's treatise Chapter 17 [23]. The Table 17.III in Ref. [23] reports the band positions of a wide range of phosphates and arsenates. The band positions for the monohydrogen phosphate anion of disodium hydrogen phosphate dihydrate is given as $v_{1}$ at 820 and $866 \mathrm{~cm}^{-1}, v_{2}$ at around $460 \mathrm{~cm}^{-1}, v_{3}$ as 953 , 993, 1055, 1070, 1120 and $1135 \mathrm{~cm}^{-1}, v_{4}$ at 520, 539, 558, 
Table 1

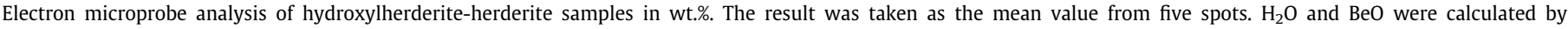
stoichiometry.

\begin{tabular}{|c|c|c|c|c|c|c|c|c|c|c|c|c|c|c|c|c|}
\hline Sample & $\mathrm{P}_{2} \mathrm{O}_{5}$ & & $\mathrm{MnO}$ & & $\mathrm{FeO}$ & & $\mathrm{CaO}$ & & $\mathrm{Al}_{2} \mathrm{O}_{3}$ & & $\mathrm{BeO}$ & $\mathrm{F}$ & & $\mathrm{H}_{2} \mathrm{O}$ & $\mathrm{O}=\mathrm{F}$ & Total \\
\hline SAA-073 & 41.86 & $\begin{array}{l}40.94- \\
42.73\end{array}$ & 0.15 & $\begin{array}{l}0.00- \\
0.65\end{array}$ & 0.01 & $\begin{array}{l}0.00- \\
0.02\end{array}$ & 33.29 & $\begin{array}{l}32.65- \\
33.79\end{array}$ & 0.02 & $\begin{array}{l}0.00- \\
0.05\end{array}$ & 15.52 & 0.24 & $\begin{array}{l}0.09- \\
0.37\end{array}$ & 5.28 & -0.10 & 96.28 \\
\hline SAA-074 & 42.57 & $\begin{array}{l}41.95- \\
43.03\end{array}$ & 0.01 & $\begin{array}{l}0.00- \\
0.03\end{array}$ & 0.01 & $\begin{array}{l}0.00- \\
0.04\end{array}$ & 33.89 & $\begin{array}{l}33.61- \\
34.30\end{array}$ & 0.02 & $\begin{array}{l}0.00- \\
0.06\end{array}$ & 15.52 & 0.07 & $\begin{array}{l}0.00- \\
0.15\end{array}$ & 5.42 & -0.03 & 97.50 \\
\hline SAA-075 & 42.46 & $\begin{array}{l}41.56- \\
43.55\end{array}$ & 0.07 & $\begin{array}{l}0.03- \\
0.13\end{array}$ & 0.01 & $\begin{array}{l}0.00- \\
0.06\end{array}$ & 33.73 & $\begin{array}{l}33.45- \\
33.93\end{array}$ & 0.02 & $\begin{array}{l}0.00- \\
0.03\end{array}$ & 15.48 & 1.90 & $\begin{array}{l}1.75- \\
2.05\end{array}$ & 4.53 & -0.80 & 97.42 \\
\hline SAA-076 & 42.85 & $\begin{array}{l}42.42- \\
43.68\end{array}$ & 0.02 & $\begin{array}{l}0.00- \\
0.03\end{array}$ & 0.01 & $\begin{array}{l}0.00- \\
0.04\end{array}$ & 34.19 & $\begin{array}{l}33.71- \\
34.46\end{array}$ & 0.02 & $\begin{array}{l}0.00- \\
0.06\end{array}$ & 15.43 & 4.46 & $\begin{array}{l}4.19- \\
4.59\end{array}$ & 3.37 & -1.88 & 98.49 \\
\hline SAA-093 & 42.23 & $\begin{array}{l}41.76- \\
43.11\end{array}$ & 0.03 & $\begin{array}{l}0.00- \\
0.07\end{array}$ & 0.01 & $\begin{array}{l}0.00- \\
0.05\end{array}$ & 32.59 & $\begin{array}{l}32.14- \\
32.92\end{array}$ & 0.01 & $\begin{array}{l}0.00- \\
0.03\end{array}$ & 15.43 & 8.01 & $\begin{array}{l}7.73- \\
8.20\end{array}$ & 1.58 & -3.39 & 96.56 \\
\hline $20,517^{\mathrm{b}}$ & 43.98 & - & ND & - & 0.01 & - & 34.99 & - & 0.01 & - & 15.54 & 5.71 & - & 2.90 & -2.40 & 100.76 \\
\hline Herderite $^{a}$ & 43.53 & & 0.00 & & 0.00 & & 34.39 & & 0.00 & & 15.34 & 11.65 & & 0.00 & & 100.00 \\
\hline \multirow[t]{2}{*}{ Hydroxylherderite ${ }^{a}$} & 44.06 & & 0.00 & & 0.00 & & 34.82 & & 0.00 & & 15.53 & 0.00 & & 5.59 & & 100.00 \\
\hline & $\mathrm{P}$ & & Mn & & $\mathrm{Fe}$ & & $\mathrm{Ca}$ & & $\mathrm{Al}$ & & $\mathrm{Be}$ & $\mathrm{F}$ & & $\mathrm{OH}$ & & \\
\hline SAA-073 & 0.99 & & 0.00 & & 0.00 & & 0.99 & & 0.00 & & 1 & 0.02 & & 0.98 & & 3.98 \\
\hline SAA-074 & 0.99 & & 0.00 & & 0.00 & & 1.00 & & 0.00 & & 1 & 0.01 & & 0.99 & & 3.99 \\
\hline SAA-075 & 0.99 & & 0.00 & & 0.00 & & 1.00 & & 0.00 & & 1 & 0.17 & & 0.83 & & 3.99 \\
\hline SAA-076 & 0.99 & & 0.00 & & 0.00 & & 1.00 & & 0.00 & & 1 & 0.39 & & 0.61 & & 3.99 \\
\hline SAA-093 & 1.00 & & 0.00 & & 0.00 & & 0.97 & & 0.00 & & 1 & 0.71 & & 0.29 & & 3.97 \\
\hline $20,517^{\mathrm{b}}$ & 0.997 & & - & & 0.000 & & 1.004 & & 0.000 & & 1 & 0.483 & & 0.517 & & 3.994 \\
\hline Herderite $^{a}$ & 1.0 & & 0.00 & & 0.00 & & 1.0 & & 0.00 & & 1.0 & 1.0 & & 0.0 & & 4.0 \\
\hline Hydroxylherderite $^{\mathrm{a}}$ & 1.0 & & 0.00 & & 0.00 & & 1.0 & & 0.00 & & 1.0 & 0.0 & & 1.0 & & 4.0 \\
\hline
\end{tabular}

a Calculated on the basis of ideal formula of herderite-( $\mathrm{CaBe}\left(\mathrm{PO}_{4}\right)(\mathrm{F})$ and hydroxylherderite- $(\mathrm{CaBe}(\mathrm{PO} 4)(\mathrm{OH})$.

b According to Harlow and Hawthorne [19].

$575 \mathrm{~cm}^{-1}$. The $\mathrm{POH}$ unit has vibrations associated with the $\mathrm{OH}$ specie. The stretching vibration of the $\mathrm{POH}$ units was tabulated as 2430 and $2870 \mathrm{~cm}^{-1}$, and bending modes at 766 and $1256 \mathrm{~cm}^{-1}$. Water stretching vibrations were found at 3050 and $3350 \mathrm{~cm}^{-1}$. The position of the bands for the disodium hydrogen phosphate is very dependent on the waters of hydration. There have been several Raman spectroscopic studies of the monosodium dihydrogen phosphate chemicals [33-37].

\section{Raman and infrared spectroscopy}

The Raman spectrum of hydroxylherderite is illustrated in Fig. 1. Clearly there are large parts of the spectrum where no intensity is observed. Therefore, the spectra are subdivided into sections according to the types of molecular vibrations being observed. The infrared spectrum of hydroxylherderite is shown in Fig. 2. As with the Raman spectrum, no intensity is observed in large parts of the spectrum and as a consequence, the spectrum may be subdivided into sections according to the types of vibrations being observed. The Raman spectra of the three samples shown (samples SAA073,

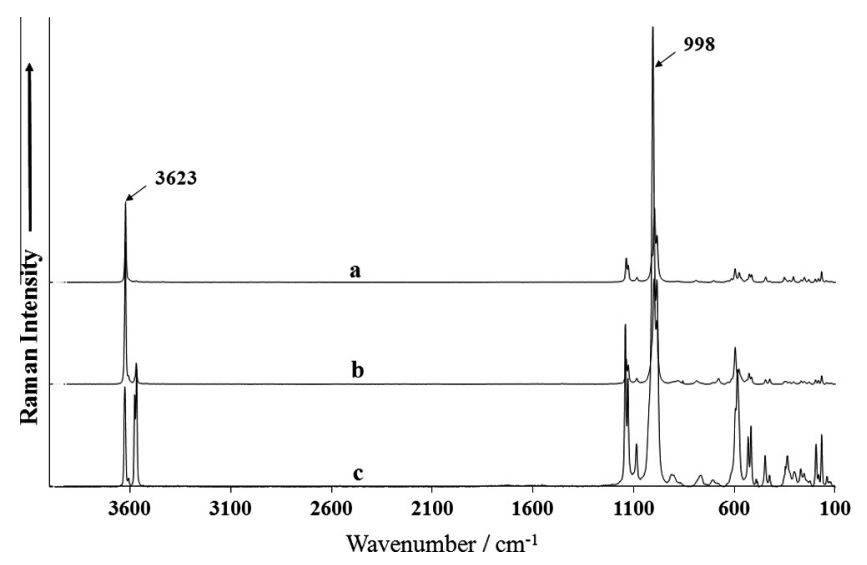

Fig. 1. Raman spectra of hydroxylherderite in the $100-4000 \mathrm{~cm}^{-1}$ region.

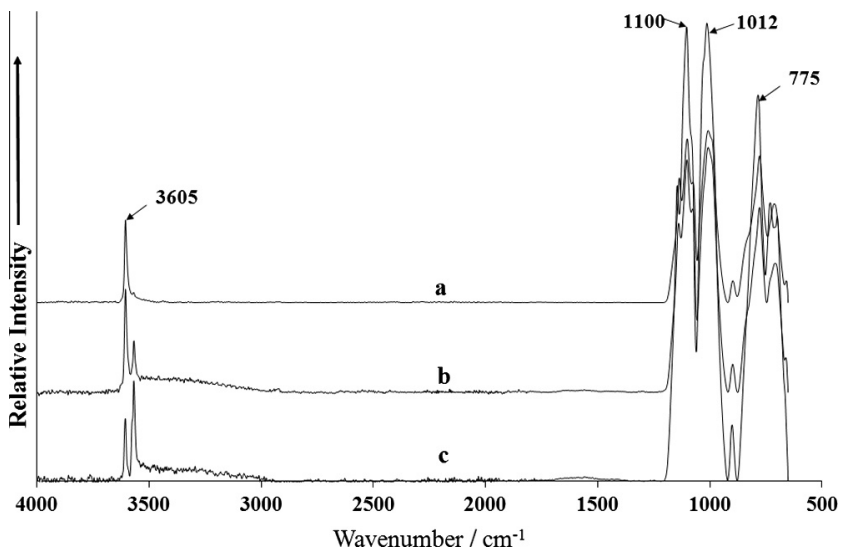

Fig. 2. Infrared spectra of hydroxylherderite in the $500-4000 \mathrm{~cm}^{-1}$ region.

SAA075 and SAA076) in this spectral region are very similar, although some variation in band position is observed.

The Raman band at $998 \mathrm{~cm}^{-1}$ of hydroxylherderite is assigned to the $v_{1}$ symmetric stretching mode of the $\mathrm{PO}_{4}^{3-}$ units. The band is observed at $1000 \mathrm{~cm}^{-1}$ for sample b and $1006 \mathrm{~cm}^{-1}$ for sample c. The Raman spectrum of herderite displays a band at $975 \mathrm{~cm}^{-1}$. Raman spectra of herderite were found very difficult to obtain because of fluorescence. The band at $985 \mathrm{~cm}^{-1}$ for hydroxylherderite is attributed to the $\mathrm{HOPO}_{3}^{3-}$ units. Galy [35] first studied the polarized Raman spectra of the $\mathrm{H}_{2} \mathrm{PO}_{4}^{-}$anion. Choi et al. reported the polarization spectra of $\mathrm{NaH}_{2} \mathrm{PO}_{4}$ crystals. Casciani and Condrate [38] published spectra on brushite and monetite together with synthetic anhydrous monocalcium phosphate $\left(\mathrm{Ca}\left(\mathrm{H}_{2} \mathrm{PO}_{4}\right)_{2}\right)$, monocalcium dihydrogen phosphate hydrate $\left(\mathrm{Ca}\left(\mathrm{H}_{2} \mathrm{PO}_{4}\right)_{2} \cdot \mathrm{H}_{2} \mathrm{O}\right)$ and octacalcium phosphate $\left(\mathrm{Ca}_{8} \mathrm{H}_{2}\left(\mathrm{PO}_{4}\right)_{6} \cdot 5 \mathrm{H}_{2} \mathrm{O}\right)$. These authors determined band assignments for $\mathrm{Ca}\left(\mathrm{H}_{2} \mathrm{PO}_{4}\right)$ and reported bands at 1012 and $1085 \mathrm{~cm}^{-1}$ as $\mathrm{POH}$ and PO stretching vibrations, respectively. The two Raman bands at 1128 and $1138 \mathrm{~cm}^{-1}$ are attributed to both the HOP and PO antisymmetric stretching 
vibrations. Casciani and Condrate [38] tabulated Raman bands at 1132 and $1155 \mathrm{~cm}^{-1}$ and assigned these bands to $\mathrm{P}-\mathrm{O}$ symmetric and the $\mathrm{P}-\mathrm{O}$ antisymmetric stretching vibrations. It is proposed that the proton on the hydroxyl units is very liable and can oscillate between the $\mathrm{OH}$ units and the phosphate units. In this way the hydrogen phosphate units are formed. Raman bands in the $883-908 \mathrm{~cm}^{-1}$ are assigned to hydroxyl deformation modes. The position and number of bands in this part of the spectrum is a function of the degree of fluorine substitution. In sample a, it is suggested that the amount of hydroxyl units is low, when compared with samples $\mathrm{b}$ and $\mathrm{c}$ where distinct $\mathrm{OH}$ deformation modes are observed.

The infrared spectrum of hydroxylherderite (Fig. 2) shows very intense bands at $1012 \mathrm{~cm}^{-1}$ assigned to the $v_{1}$ symmetric stretching mode of the $\mathrm{PO}_{4}^{3-}$ units. The infrared spectrum of herderite shows an intense band at $1005 \mathrm{~cm}^{-1}$ and is attributed to this vibration. The infrared bands at around $1100 \mathrm{~cm}^{-1}$ are assigned to the $v_{3}$ antisymmetric stretching mode of the $\mathrm{PO}_{4}^{3-}$ units. The infrared bands of herderite at 1079, 1099, 1121 and $1149 \mathrm{~cm}^{-1}$ are assigned to this vibrational mode.

Some variation in peak position and intensity is observed in the Raman spectra of the three hydroxylherderite samples. The set of Raman bands of hydroxylherderite observed at 563, 568, 577, 598, 616 and $633 \mathrm{~cm}^{-1}$ (sample a), 568, 579, 597, 616 and $534 \mathrm{~cm}^{-1}$ and 578, 586, 597 and $614 \mathrm{~cm}^{-1}$ (sample c) are assigned to the $v_{4}$ out of plane bending modes of the $\mathrm{PO}_{4}$ and $\mathrm{H}_{2} \mathrm{PO}_{4}$ units. The Raman bands in this part of the spectral region for herderite were swamped by fluorescence. The Raman spectrum of $\mathrm{NaH}_{2} \mathrm{PO}_{4}$ shows Raman bands at 526, 546 and $618 \mathrm{~cm}^{-1}$. The observation of multiple bands in this spectral region supports the concept of symmetry reduction of both the phosphate and hydrogen phosphate units. The Raman bands at 425 and $446 \mathrm{~cm}^{-1}$ together with the bands at 516 and $527 \mathrm{~cm}^{-1}$ (sample a), 426, 447, 516 and $528 \mathrm{~cm}^{-1}$ (sample b) and 427, 449, 493, 529 and $533 \mathrm{~cm}^{-1}$ (sample c) are attributed to the $v_{2} \mathrm{PO}_{4}$ and $\mathrm{H}_{2} \mathrm{PO}_{4}$ bending modes. The Raman spectrum of $\mathrm{NaH}_{2} \mathrm{PO}_{4}$ shows two Raman bands at 460 and $482 \mathrm{~cm}^{-1}$. The observation of multiple Raman bands for the hydroxylherderite mineral supports the concept of symmetry reduction.

A number of bands are observed in the $300-350 \mathrm{~cm}^{-1}$ region. Raman bands are found at 308, 327, 346 and $354 \mathrm{~cm}^{-1}$ (sample a), 307, 328, 343 and $352 \mathrm{~cm}^{-1}$ (sample b) and 303, 325, 339, 349 and $355 \mathrm{~cm}^{-1}$ are attributed to $\mathrm{BeO}$ and $\mathrm{CaO}$ stretching vibrations. Some varaition in band position and intensity is observed. This is expected as these bands are due to external or often called lattice vibrations. Strong Raman bands are found at 145, 168, 184, $199,232,254$ and $270 \mathrm{~cm}^{-1}$ (sample a), 168, 184, 198, 230, 254 and $170 \mathrm{~cm}^{-1}$ (sample b), 168, 183, 196, 254 and $272 \mathrm{~cm}^{-1}$ (sample c).

The Raman spectrum of the $\mathrm{OH}$ stretching region may be observed in Fig. 1.

This spectral region is where the $\mathrm{OH}$ stretching vibrations are observed. In this spectral region, considerable variation in intensity is observed. For sample a, a single intense Raman band at $3623 \mathrm{~cm}^{-1}$ is observed with a low intensity shoulder at $3622 \mathrm{~cm}^{-1}$. Another low intensity band is observed at $3570 \mathrm{~cm}^{-1}$. This latter band shows greater intensity for sample b. For this sample a very intense band at $3624 \mathrm{~cm}^{-1}$ is found, now with a low intensity shoulder at $3627 \mathrm{~cm}^{-1}$. A low intensity band at $3609 \mathrm{~cm}^{-1}$ is also found. The band at $3570 \mathrm{~cm}^{-1}$ for hydroxylherderite samples a and b now is split into two bands at 3568 and $3578 \mathrm{~cm}^{-1}$ for sample $\mathrm{c}$ and shows much greater intensity. The Raman spectrum of herderite displays an intense sharp band at $3625 \mathrm{~cm}^{-1}$ with a low intensity shoulder on the low wavenumber side of the main peak. It is significant that there are two $\mathrm{OH}$ stretching vibrations; thus, indicating that there are two nonequivalent $\mathrm{OH}$ units.
The infrared spectrum of sample a shows a very intense band at $3605 \mathrm{~cm}^{-1}$ with low wavenumber shoulders at 3569 and $3597 \mathrm{~cm}^{-1}$ (Fig. 2). The infrared spectrum is in good harmony with the Raman spectrum of this sample. The infrared spectrum for sample b displays an intense band at $3605 \mathrm{~cm}^{-1}$ with shoulders at 3570 and $3599 \mathrm{~cm}^{-1}$. These bands are attributed to the $\mathrm{OH}$ stretching vibration. Two peaks of around equal intensity for herderite are observed at 3567 and $3575 \mathrm{~cm}^{-1}$. The observation of multiple bands supports the concept that the $\mathrm{OH}$ units are not equivalent. The $\mathrm{OH}$ peaks are superimposed upon a broad feature centered around $3640 \mathrm{~cm}^{-1}$ and attributed to adsorbed water. For sample c, two intense infrared peaks are observed at 3566 and $3605 \mathrm{~cm}^{-1}$ with a shoulder band at $3600 \mathrm{~cm}^{-1}$. Again, the $\mathrm{OH}$ stretching peaks are superimposed upon a broad low intensity feature centered around $3311 \mathrm{~cm}^{-1}$. There is good correlation between the infrared and Raman spectra. The observation of two $\mathrm{OH}$ stretching vibrations gives credence to the non-equivalence of the $\mathrm{OH}$ units in the herderite-hydroxylherderite structure. Such information is not available using other techniques such as X-ray diffraction.

Studies have shown a strong correlation between $\mathrm{OH}$ stretching frequencies and both $\mathrm{O} \ldots \mathrm{O}$ bond distances and $\mathrm{H} \ldots \mathrm{O}$ hydrogen bond distances [39-42]. Libowitzky showed that a regression function can be employed relating the hydroxyl stretching wavenumbers with regression coefficients better than 0.96 using infrared spectroscopy [43]. The function is described as: $v_{1}$ $=(3592-304) \times 109^{\frac{-d(0-O)}{0.1321}} \mathrm{~cm}^{-1}$. Thus OH ... O hydrogen bond distances may be calculated using the Libowitzky empirical function. Hydrogen bond distances may be obtained by using the $\mathrm{OH}$ stretching wavenumbers as given in Fig. 1. The values for the $\mathrm{OH}$ stretching vibrations listed above provide hydrogen bond distances of $2.9497 \AA\left(3531 \mathrm{~cm}^{-1}\right), 3.0785 \AA\left(3569 \mathrm{~cm}^{-1}\right), 3.1070 \AA$ $\left(3597 \mathrm{~cm}^{-1}\right), 3.1560 \AA\left(3605 \mathrm{~cm}^{-1}\right)$. By using the position of the Raman $\mathrm{OH}$ stretching wavenumbers as given in Fig. 2, hydrogen bond distances may be estimated. Here, hydrogen bond distances are calculated as $3.0231 \AA\left(3557 \mathrm{~cm}^{-1}\right), 3.0729 \AA\left(3568 \mathrm{~cm}^{-1}\right)$, $3.1441 \AA \quad\left(3578 \mathrm{~cm}^{-1}\right), \quad 3.1561 \AA \quad\left(3609 \mathrm{~cm}^{-1}\right), \quad 3.2530 \AA$ $\left(3626 \mathrm{~cm}^{-1}\right)$. It is observed that the hydrogen bond distances calculated from the infrared spectra are in a similar range as calculated from the Raman spectrum.

The large hydrogen bond distances which are present in hydroxylherderite can also be seen in other mixed anion minerals such as peisleyite and perhamite $[44,45]$ where the distances ranging between 3.052(5) and 2.683(6) Å. Such hydrogen bond distances are typical of secondary minerals. A range of hydrogen bond distances are observed from reasonably strong to weak hydrogen bonding. This range of hydrogen bonding contributes to the stability of the mineral. Two types of $\mathrm{OH}$ units can be identified in the structure of hydroxylherderite. Structural data (X-ray diffraction) do not give us such information (Lager and Gibbs [18], Harlow and Hawthorn [19]). Importantly, for all of the members of the herderite-hydroxylherderite series, two $\mathrm{OH}$ stretching vibrations are observed. This shows that there are two non-equivalent $\mathrm{OH}$ units in the mineral structure. The duplication of the hydroxyl stretching vibrations is also observed in the NIR spectra (see below).

The hydrogen bond distances previously established can be used to predict the hydroxyl stretching wavenumbers. The spectrum of hydroxylherderite may be divided into two groups of $\mathrm{OH}$ stretching wavenumbers; namely $3500-3600 \mathrm{~cm}^{-1}$ and 3600 $3650 \mathrm{~cm}^{-1}$. This distinction suggests that the strength of the hydrogen bonds as measured by the hydrogen bond distances can also be divided into two groups according to the H-bond distances. An arbitrary cut-off point may be $3.40 \AA$ based upon the wavenumber $3590 \mathrm{~cm}^{-1}$. Thus the first bands listed above may be described as weak hydrogen bonds and the last two bands as 
relatively strong hydrogen bonds. It should be noted that the infrared band at $1635 \mathrm{~cm}^{-1}$ is assigned to the water $\mathrm{HOH}$ bending mode (figure not shown). For normal hydrogen-bonded water this band occurs at around $1620 \mathrm{~cm}^{-1}$. Thus the position of this band also indicates relatively weak hydrogen bonding in the mineral hydroxylherderite.

\section{Near Infrared spectroscopy (NIR)}

The near infrared spectra of (a) herderite, (b) hydroxylherderite-SAA073, intensity has been multiplied a factor of 2 , (c) hydroxylherderite-SAA074, intensity has been multiplied a factor of 4, (d) hydroxylherderite-SAA075, intensity has been multiplied a factor of 2, and (e) hydroxylherderite-SAA076, intensity has been multiplied a factor of 5 are shown in Fig. 3. This figure shows obvious differences in the spectra of the five minerals of the herderitehydroxylherderite series. Near-infrared spectroscopy is often referred to as proton spectroscopy. The reason is that the near infrared spectrum, in the main, contains the combination and overtones bands of the hydroxyl bands of the mid-infrared spectral range. Thus, any units which contain protons such as hydroxyl, amine, and $\mathrm{CH}$ will show bands in the NIR spectral region.

The spectra may be conveniently divided into sections. The NIR spectral region between 4000 and $6000 \mathrm{~cm}^{-1}$ region is the region where combination bands of the $\mathrm{OH}$ vibrations in the mid-infrared spectral region. The region between 6000 and $8000 \mathrm{~cm}^{-1}$ displays the bands which are the combination and overtone bands of the hydroxyl stretching bands from the mid-IR. The spectra in this spectral range are illustrated in Fig. 4. The spectral region between 10,000 and $12,000 \mathrm{~cm}^{-1}$ display bands which are due to the second overtone of $\mathrm{OH}$ stretching vibration of the mid-infrared spectrum. The spectra are reported in Fig. 5.

The NIR spectrum of herderite shows two bands at 6977 and $7058 \mathrm{~cm}^{-1}$. The infrared spectrum of herderite displays two bands at 3567 and $3575 \mathrm{~cm}^{-1}$ assigned to the $\mathrm{OH}$ stretching vibrations. The bands at 6977 and $7058 \mathrm{~cm}^{-1}$ are attributed to the first overtone of the $\mathrm{OH}$ stretching fundamental. These bands are assigned to $2 v_{\mathrm{OH}}$. An additional band of lower intensity is observed at

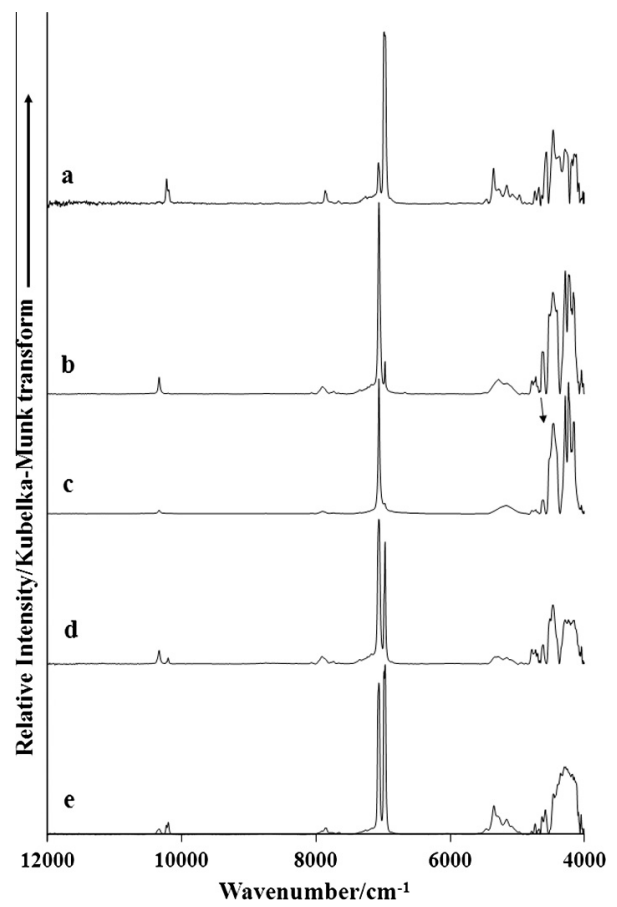

Fig. 3. Near-infrared spectrum of herderite-hydroxylherderite in the 4000$12,000 \mathrm{~cm}^{-1}$ region (samples SAA-073, 074, 075, 076 and 093).

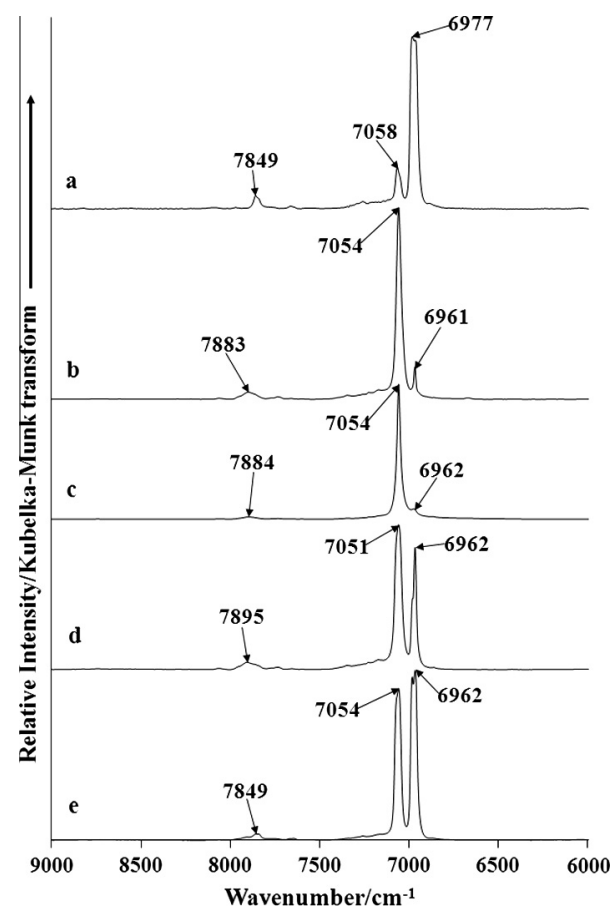

Fig. 4. Near-infrared spectrum of herderite-hydroxylherderite in the 6000$9000 \mathrm{~cm}^{-1}$ region (samples SAA-073, 074, 075, 076 and 093).

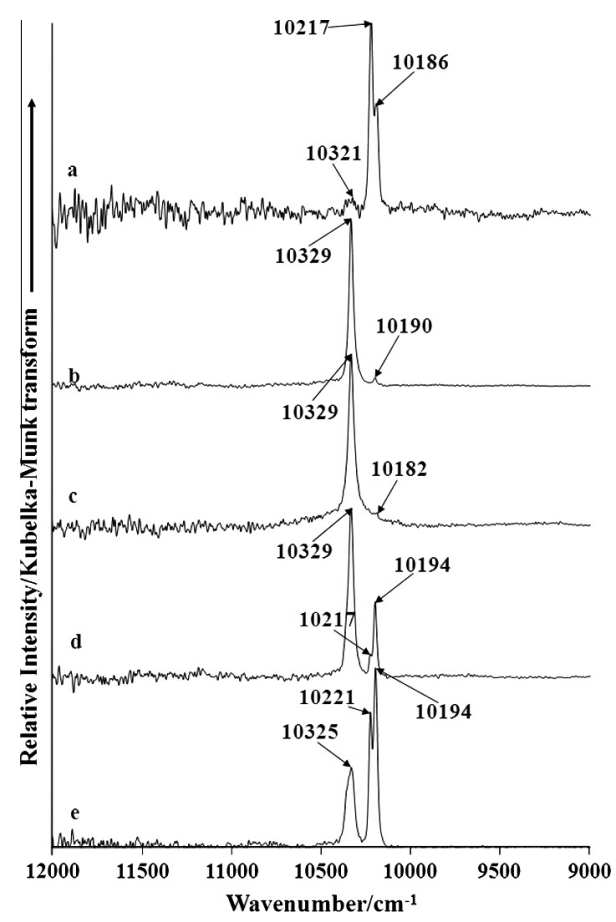

Fig. 5. Near-infrared spectrum of herderite-hydroxylherderite in the 90,000$12,000 \mathrm{~cm}^{-1}$ region (samples SAA-073, 074, 075, 076 and 093).

$7849 \mathrm{~cm}^{-1}$. This band is due to the combination of the stretching and deformation modes in the mid-infrared spectrum $\left(2 v_{\mathrm{OH}}+\delta_{\mathrm{OH}}\right)$ i.e. the band is due to the first overtone of the $\mathrm{OH}$ stretching fundamental and the $\mathrm{OH}$ deformation mode.

The NIR spectrum of hydroxylherderite (spectra b to e) displays two bands at around 6961 and $7054 \mathrm{~cm}^{-1}$. The position of the bands remains constant but the intensity of the bands varies and appears to be a function of the fluorine content in the mineral as 
Table 2

Variations of infrared, Raman and NIR OH bands and measured fluorine and calculated $\mathrm{H}_{2} \mathrm{O}$ contents in wt.\%.

\begin{tabular}{|c|c|c|c|c|c|c|}
\hline & SAA-073 & SAA-074 & SAA-075 & SAA-076 & SAA-093 & $20,517^{a}$ \\
\hline wt.\% (F) & 0.24 & 0.07 & 1.90 & 4.46 & 8.01 & 5.71 \\
\hline $\mathrm{N}^{\circ}$ atoms $(\mathrm{F})$ & 0.02 & 0.01 & 0.17 & 0.39 & 0.71 & 0.483 \\
\hline wt.\% $\left(\mathrm{H}_{2} \mathrm{O}\right)$ & 5.28 & 5.42 & 4.53 & 3.37 & 1.58 & 2.90 \\
\hline $\mathrm{N}^{\circ}$ atoms $(\mathrm{OH})$ & 0.98 & 0.99 & 0.83 & 0.61 & 0.29 & 0.517 \\
\hline $\mathrm{F} /(\mathrm{OH}+\mathrm{F})$ & 0.02 & 0.01 & 0.17 & 0.39 & 0.71 & 0.483 \\
\hline $\operatorname{IR} v_{\mathrm{OH}}\left(\mathrm{cm}^{-1}\right)$ & 3605,3597 & 3605, 3599 & $3605,3600,3566$ & 3606 & 3575,3567 & - \\
\hline $\operatorname{IR} \delta_{\mathrm{OH}}\left(\mathrm{cm}^{-1}\right)$ & 776 & 773 & 776 & 776 & 788 & - \\
\hline Raman & 3623 & 3623 & 3624,3609 & $3626,3609,360$ & - & 3625.8 \\
\hline NIR $2 v_{\mathrm{OH}}$ & 7054,6961 & 7054,6962 & 7051,6962 & 7054,6962 & 7058,6977 & - \\
\hline NIR $3 v_{\mathrm{OH}}$ & $10,329,10,190$ & $10,329,10,182$ & $10,329,10,194$ & $10,325,10,194$ & $10,321,10,186$ & - \\
\hline
\end{tabular}

a According to Harlow and Hawthorne [19] and Harlow (personal communication).

reported in Table 2 . The higher the fluorine content the greater the intensity of the $6962 \mathrm{~cm}^{-1}$ band. A low intensity NIR band is observed at around $7883 \mathrm{~cm}^{-1}$. The position of this band appears to vary with the fluorine content. The position of the band $\left(7849 \mathrm{~cm}^{-1}\right)$ is the same for the high fluorine content hydroxylherderite and herderite.

This spectral region is where the second overtone of the hydroxyl stretching fundamental that is $3 v_{\mathrm{OH}}$. The mineral herderite displays two bands at 10,186 and $10,217 \mathrm{~cm}^{-1}$ with a very weak band at $10,321 \mathrm{~cm}^{-1}$ (spectrum a). The two hydroxylherderite minerals with very low $F$ content shows an intense band at $10,329 \mathrm{~cm}^{-1}$ with a very low intensity band at $10,190 \mathrm{~cm}^{-1}$. For the two higher F content hydroxylherderite minerals two intense bands are observed at 10,194 and $10,329 \mathrm{~cm}^{-1}$. The hydroxylherderite (spectrum e) has an additional band at $10,221 \mathrm{~cm}^{-1}$. This band is also observed as a shoulder band in spectrum (d). It should be kept in mind that there are no quantum mechanical restrictions on the allowed vibrations on NIR spectroscopy. The combination of infrared and Raman bands is allowed. What is quite clear is that NIR spectroscopy shows differences in the spectra of the minerals and this is related to the $\mathrm{F}$ content of the minerals.

\section{Conclusions}

The samples associated to montebrasite and lepidolite rich pegmatites show lower fluorine values (SAA-073 - 0.24\%; SAA-074 $0.07 \%$; SAA- $075-1.90 \%$ ) and the sample associated to triphylite rich pegmatite shows intermediate fluorine content (SAA-076 $4.46 \%$ ), while the analyzed sample from a muscovite and topaz rich pegmatite shows high fluorine (SAA-093 - 8.01\%). This relationship may be explained in relation with the degree of differentiation of the pegmatite magma, where lithium rich pegmatites shows lower content of fluorine with predominance of hydroxylherderite in the hydrothermal system and the muscovite topaz rich pegmatite shows higher fluorine content with predominance of the $\mathrm{F}$ rich member herderite.

In the vibrational spectroscopic study, the Raman spectra of hydroxylherderite are characterized by bands at around 985 and $998 \mathrm{~cm}^{-1}$, assigned to $v_{1}$ symmetric stretching mode of the $\mathrm{PO}_{4}^{3-}$ units. Raman bands at around 1085, 1128 and $1138 \mathrm{~cm}^{-1}$ are attributed to both the HOP and PO antisymmetric stretching vibrations. The set of Raman bands observed at 563, 568, 577, 598, 616 and $633 \mathrm{~cm}^{-1}$ are assigned to the $v_{4}$ out of plane bending modes of the $\mathrm{PO}_{4}$ units. The $\mathrm{OH}$ Raman stretching vibrations of hydroxylherderite were observed ranging from $3626 \mathrm{~cm}^{-1}$ to $3609 \mathrm{~cm}^{-1}$. The infrared stretching vibrations of hydroxylherderites were observed between $3606 \mathrm{~cm}^{-1}$ and $3599 \mathrm{~cm}^{-1}$. The significance of two stretching vibrations in the $\mathrm{OH}$ stretching region, proves that there are two non-equivalent $\mathrm{OH}$ units in the structure of the herderitehydroxylherderite series.
By using a Libowitzky type function, hydrogen bond distances based upon the infrared and Raman $\mathrm{OH}$ stretching band wavenumbers were calculated. By using the infrared $\mathrm{OH}$ stretching vibrations for sample SAA-073 the calculated hydrogen bond distances are: $2.9497 \AA \quad\left(3531 \mathrm{~cm}^{-1}\right), \quad 3.0785 \AA \quad\left(3569 \mathrm{~cm}^{-1}\right), \quad 3.1070 \AA$ $\left(3597 \mathrm{~cm}^{-1}\right), 3.1560 \AA\left(3605 \mathrm{~cm}^{-1}\right)$. In agreement with the infrared data, the Raman $\mathrm{OH}$ stretching vibrations for sample SAA-076 shows similar values of calculated hydrogen bond distances, given as $3.0231 \AA \quad\left(3557 \mathrm{~cm}^{-1}\right), \quad 3.0729 \AA \quad\left(3568 \mathrm{~cm}^{-1}\right), \quad 3.1441 \AA$ $\left(3578 \mathrm{~cm}^{-1}\right), 3.1561 \AA\left(3609 \mathrm{~cm}^{-1}\right), 3.2530 \AA \AA\left(3626 \mathrm{~cm}^{-1}\right)$.

Near infrared spectroscopy was used to characterize the herderite-hydroxylherderite minerals. Characteristic NIR bands at around 6961 and $7054 \mathrm{~cm}^{-1}$ were assigned to the first overtone of the fundamental, whilst NIR bands at 10,194 and $10,329 \mathrm{~cm}^{-1}$ are assigned to the second overtone of the fundamental $\mathrm{OH}$ stretching vibration.

The position and intensity of the infrared and near-infrared $\mathrm{OH}$ stretching bands show variations with fluorine content of the herderite-hydroxylherderite mineral series, in a similar correlation to that published data for amblygonite-montebrasite series $[21,22]$. The IR $v_{\mathrm{OH}}$ bands for samples SAA-073 $\left(\mathrm{He}_{0.01} \mathrm{Hy} y_{0.99}\right)$ and SAA-093 $\left(\mathrm{He}_{0.71} H y_{0.29}\right)$ are $3605,3597 \mathrm{~cm}^{-1}$ and $3575,3567 \mathrm{~cm}^{-1}$ respectively, and shows an increase of the position with increase of $\mathrm{F}$ content. The same correlation can be observed in the same samples in NIR $3 v_{\mathrm{OH}}$ bands. IR $\delta_{\mathrm{OH}}$ bands where assigned at $776 \mathrm{~cm}^{-1}$ and $788 \mathrm{~cm}^{-1}$ and NIR $2 v_{\mathrm{OH}}$ bands where observed at $7054,6961 \mathrm{~cm}^{-1}$ and $7058,6977 \mathrm{~cm}^{-1}$ respectively, and shows an inverse correlation with decrease of position with increase of F content.

\section{Acknowledgements}

The financial and infra-structure support of the Discipline of Nanotechnology and Molecular Science, Science and Engineering Faculty of the Queensland University of Technology, is gratefully acknowledged. The Australian Research Council (ARC) is thanked for funding the instrumentation. R. Scholz thanks to CNPq - Conselho Nacional de Desenvolvimento Científico e Tecnológico (Grant No. 306287/2012-9). M. Cândido Filho thanks to CNPq/PIBIC/UFOP.

\section{References}

[1] H.G. Dill, Earth Sci. Rev. 100 (2010) 1-420.

[2] D.M. Burt, Met. Assoc. Acid Magmat. 1 (1974) 262-266.

[3] K. Rickers, R. Thomas, W.W. Heinrich, Min. Dep. 41 (2006) 229-245.

[4] R. Thomas, J.D. Webster, P. Davidson, Cont. Min. Pet. 161 (2011) 483-495.

[5] P.B. Moore, Min. Rec. 4 (1973) 103-130.

[6] D.M. Burt, Econ. Geol. 70 (1975) 1279-1292.

[7] P. Černý, Rev. Min. Geochem. 50 (2002) 405-444.

[8] I. Černá, P. Černý, J.B. Selway, R. Chapman, Can. Min. 40 (2002) 1339-1345.

[9] D. Atencio, J.M.V. Coutinho, L.A.D. Menezes, Axis 1 (2005) 1-18.

[10] D. Atencio, P.A. Matioli, J.B. Smith, N.V. Chukanov, J.M.V. Coutinho, R.K. Rastsvetaeva, S. Möckel, Amer. Min. 93 (2008) 1-6. 
[11] P.J. Dunn, W. Wight, J. Gem. 15 (1976) 27-28.

[12] P.J. Dunn, C.W. Wolfe, P.B. Leavens, W.E. Wilson, Min. Rec. 10 (1979) 5-11.

[13] R.C. Kammerling, K. Scarratt, G. Bosshart, E.A. Jobbins, R.E. Kane, E.J. Gübelin, A.A. Levinson, J. Gem. 24 (1994) 3-40.

[14] W. Haidinger, Phil. Mag. Annals Phil. (London) New Series 4 (1828) 1-3.

[15] S.L. Penfield, Amer. J. Sci. 147 (1894) 329-339.

[16] C. Palache, H. Berman, C. Frondel, Dana's System of Mineralogy, seventh ed., Wiley, New York, 1951.

[17] K. Byrappa, D.Y. Pushcharovsky, Prog. Cryst. Growth Char. Mat. 24 (1992) 269359.

[18] G.A. Lager, G.V. Gibbs, Amer. Min. 59 (1974) 919-925.

[19] G.E. Harlow, F.C. Hawthorne, Amer. Min. 93 (2008) 1545-1549.

[20] P.B. Leavens, P.J. Dunn, R.V. Gaines, Amer. Min. 63 (1978) 913-917.

21] A.M. Fransolet, P. Tarte, Amer. Min. 62 (1977) 559-564.

[22] B. Rondeau, E. Fritsch, P. Lefevre, M. Guiraud, A.-M. Fransolet, Y. Lulzac, Can. Min. 44 (2006) 1109-1117.

[23] V.C. Farmer, Mineralogical Society Monograph 4: The Infrared Spectra of Minerals, London, 1974

[24] R.L. Frost, K.L. Erickson, Spectrochim. Acta 61A (2004) 45-50.

[25] R.L. Frost, W. Martens, P.A. Williams, J.T. Kloprogge, Min. Mag. 66 (2002) 1063 1073.

[26] R.L. Frost, W. Martens, P.A. Williams, J.T. Kloprogge, J. Raman Spectrosc. 34 (2003) 751-759.

[27] R.L. Frost, W.N. Martens, T. Kloprogge, P.A. Williams, Neues Jahrb. Min. (2002) 481-496.

[28] R.L. Frost, M.L. Weier, J. Mol. Struct. 697 (2004) 207-211.
[29] K. Rickers, R. Thomas, W. Heinrich, Min. Dep. 41 (2006) 229-245.

[30] M.L. Frezzoti, F. Tecce, A. Casagli, J. Geochem. Explor. 112 (2012) 1-20.

[31] U. Kolitsch, D. Atencio, N.V. Chukanov, N.V. Zubkova, L.A.D.M. Filho, J.M.V. Coutinho, W.D. Birch, J. Schlüter, D. Pohl, A.R. Kampf, I.M. Steele, G. Favreau, L. Nasdala, S. Möckel, G. Giester, D.Y. Pushcharovsky, Min. Mag. 74 (2010) 469486.

[32] R.L. Frost, P.A. Williams, W. Martens, J.T. Kloprogge, P. Leverett, J. Raman Spectrosc. 33 (2002) 260-263.

[33] C.E. Bamberger, W.R. Busing, G.M. Begun, R.G. Haire, L.C. Ellingboe, J. Solid State Chem. 57 (1985) 248-259.

[34] B.K. Choi, M.N. Lee, J.J. Kim, J. Raman Spectrosc. 20 (1989) 11-15.

[35] A. Galy, J. Phys. Radium 12 (1951) 827.

[36] H. Poulet, N. Toupry-Krauzman, Proc. Int. Conf. Raman, Spectrosc., 6th, vol. 2 , 1978, pp. 364-365.

[37] N. Toupry-Krauzman, H. Poulet, M. Le Postollec, J. Raman Spectrosc. 8 (1979) $115-121$.

[38] F.S. Casciani, R.A. Condrate, Sr., Proc. - Inter. Cong. Phosphorus Compounds, 2nd, 1980, pp. 175-190.

[39] J. Emsley, Chem. Soc. Rev. 9 (1980) 91-124.

[40] H. Lutz, Struct. Bond. 82 (1995) 85-103.

[41] W. Mikenda, J. Mol. Struct. 147 (1986) 1-15.

[42] A. Novak, Struct. Bond. 18 (1974) 177-216.

[43] E. Libowitsky, Monatsch. Chem. 130 (1999) 1047-1049.

[44] R.L. Frost, S.J. Mills, M.L. Weier, Peisleyite an unusual mixed anion mineral-a vibrational spectroscopic study, Spectrochim. Acta, Part A: Mol. Biomol. Spectrosc. 61A (2004) 177-184.

[45] R.L. Frost, M.L. Weier, S.J. Mills, Spectrochim. Acta 67A (2007) 604-610. 